\title{
Lingua-Didactic Aspects of Teaching Mining Vocabulary to Mining Engineers
}

\author{
Elena Marinova ${ }^{1}$, Nadezda Rabkina $^{1,{ }^{*}}$, Marina Ryabova $^{1}$, and Olga Valko ${ }^{1}$, \\ ${ }^{1}$ Kemerovo State University, 650000, 6 Krasnaya St., Kemerovo, Russia
}

\begin{abstract}
The current paper features the problem of teaching foreignlanguage mining vocabulary to would-be translators / interpreters and mining students. The one-industry city environment poses a challenge in front of those higher education institutions that offer a master degree in translation: as long as the best jobs in the region are offered by coal-mining enterprises, developing language and translation skills is not enough. A professional translator in a coal-mining region has to be familiar with mining vocabulary, which, like in any other high-tech production sphere, seems either too abstract or too specific for an outsider. Bachelors in coal mining, on the other hand, demonstrate a lack of communication skills if they wish to get a master degree in translation. The article states Content and Language Integrated Learning method (CLIL) as a possible solution for the problem. The method allows the instructor to employ various authentic media sources within the mining works to build up topic cases for communication skills development at the initial stage as well as to extract terminology to compile thematic glossaries at a later stage of translation skills acquisition. The paper includes some examples of CLIL application in teaching translation for coal-mining industry purposes.
\end{abstract}

\section{Introduction}

University Education in the sphere of mining engineering is a vital part of state educational policy in Kemerovo region where mining industry constitutes a major sector of economy. The university curriculum of mining engineering studies includes a foreign language (English, French, or German) as one of the obligatory subjects aiming at teaching students to communicate in an international community on the matter of mining and mineral resources. Thus, the issue of mastering the techniques and competences of understanding, learning and translating mining and mineral terminology and vocabulary is very important within the university training.

The same mining matter arises on a different level when it comes to teaching future translators, interpreters, and philologists, who possess necessary language skills but lack professional knowledge in the mining sphere - the sphere that offers the most attractive

\footnotetext{
*Corresponding author: nrabkina@mail.ru
} 
employment prospects for translators in the region where coal industry is the staple branch of economy. As a result, there is a constant ever-growing need in specialists who would possess both mining knowledge and translation skills, because the main problem with university graduates with a degree in translation is that they require a long period of additional training when employed by large mining enterprises.

The current two-step system of higher education can resolve the matter by offering bachelors in mining engineering an opportunity to get a master degree in translation. Grouping them with philology bachelors allows for a perfect teaching environment in which both groups benefit from experience sharing. This is where Content and Language Integrated Learning (CLIL) method can assist both mining and translation students in mastering sophisticated terminology within the thematic net of coal mining as well as acquiring communication skills and translation and interpreting abilities.

\section{Materials and Methods}

Teaching mining students new professional vocabulary means that providing them with a glossary of related terms is merely not enough: it is more important to provide them with a living context for each lexical unit. The task in hand proves to be more complicated when it comes to developing speaking comprehension and interpreting skills, especially when the vocabulary in question belongs to such a complex field as mining. While learning mining vocabulary for translation purposes can be reduced to mastering a number of translation equivalents, speaking skills training presupposes that students possess at least some degree of understanding of what they are speaking about - a condition that proves immeasurably difficult to reach in a group of humanities majors than it would be in a group of future mining engineers, who, in their turn, often lack language skills.

The aim to be achieved definitely requires applying CLIL methodology, whose efficiency has been proved not only within school environment, but also for vocational training [1]. CLIL is widely engaged in teaching subjects through a foreign language or with the help of a foreign language [2]. Having appeared in 1990s, thanks to David Marsh (University of Jyväskylä), the term CLIL gained popularity in 2000s. Originally, D. Marsh applied the term "to situations where subjects, or parts of subjects, are taught through a foreign language with dual-focused aims, namely the learning of content and the simultaneous learning of a foreign language" [3].

The above principle, however, is not absolutely new or groundbreaking. The variety of terms used to label similar techniques serves the evidence of wide application of the described approach: Content-based Language Teaching (CBLT), Content-based Instruction (CBI) or Content-based Language Instruction (CBLI), Bilingual Integration of Languages and Disciplines (BILD), English Across the Curriculum (EAC), English as a Medium of Instruction (EMI), Foreign Language Immersion Program (FLIP), Foreign Languages as a Medium of Education (FLAME), Teaching Content Through English and conversely Teaching English Through Content, Content and Language Integrated Project (CLIP) to name just a few [4]. Delving even deeper and contemplating the nature of the method no matter the name, one can obviously identify the natural cognitive mechanism behind it: the language acquisition in childhood goes inseparably along with the world cognition, i.e. a child acquires the language and 'learns the content' simultaneously.

According to the professional communities of teachers relying on CLIL (see The TESOL Encyclopedia of English Language Teaching, CLIL Teacher Magazine, web portals: https://www.teachingenglish.org.uk/ - supported by BBC, http://www.teacherscorner.co.uk/ - supported by Express Publishing, http://e-clil.uws.ac.uk/ - a European project funded by EU Commission, http://www.onestopenglish.com/clil// and others), the original list of subjects to be taught by CLIL includes Maths, Science, Environmental 
studies, Geography, Physical Education, Economics, Business studies, History, Media studies, Health studies, Tourism, Art, etc. The list has later expanded due to business communication teaching. Moreover, the EU Commission of the European Communities outlined similar concepts in its document "Promoting Language Learning and Linguistic Diversity: An Action Plan" [5] and put down the principles of life-long language learning, while setting out the ideas of language learning in secondary education and training, as well as in higher education.

We may resolutely claim that CLIL principle and technology work well for teaching new professional vocabulary to both mining students and would-be interpreters / translators. However, the approaches and strategies may differ considerably resulting from the difference in the prior knowledge and the aims of teaching. The mining students are familiar with the subject matter and the professional field in their native language, which entails the necessity to provide the English equivalents for a set of the already known fragments of the world; teaching language here focuses mostly on lexical problems, grammar plays secondary and supportive roles. The instructor's primary objective is to create conditions and provide contexts where the students' knowledge of mining can be transposed or 'translanguaged' [6] into the one in the foreign language. At the same time, humanities majors have a good command of language, lacking the understanding of the mining specifics and processes. The instructor needs to form the lacking worldview, generate and externalize the relevant concepts, pertaining to the area, provide names in foreign and native languages, rather than clear up or explicate the linguistic issues.

The universal recommendations of studying and supplementary materials for both types of learners stem from common sense approach and relate to concentric strategy of study, which imply studying on a "simple-to-complex" basis. Moving from one stage of the training process to another, the instructor engages the texts, whose target audience is expected to become more and more proficient in the field and terminology studied, e.g.:

(a) news and mass media texts are oriented on the general public (laymen),

(b) encyclopedic texts and subject textbooks are intended for people with little preliminary knowledge and expertise,

(c) instructive and scientific texts are written for specialists carrying out professional activities and using terminology expertly and extensively,

(d) materials for role-play and case study require a sound grasp of the field knowledge and related terminology.

Both teaching models can be briefly represented in the following Table 1.

At early stages of the educational process, dealing with news and mass media texts helps the learner familiarize with the general (non-professional) aspects of the subject field, which eventually removes the fear of failure and instills confidence at later stages and in future professional career. Then, encyclopedic texts and basic subject (mining) textbooks focus on a more specific and subject-related vocabulary than media text. Introducing them pursues different aims for each type of learners: mining students get a chance to correlate their native language worldview with the one in the foreign language and form the workable (terminological) vocabulary, while humanities students get an access to specific field area knowledge and form the worldview about the sphere they are hardly aware of and simultaneously acquire new (terminological) vocabulary. Instructive and scientific texts are to master the professional and linguistic knowledge (especially receptive skills) and bring the learners into the professional sphere. Cases and role-plays allow instructors to engage and actualize both receptive and productive skills, completing the teaching and learning process [7].

A translator's and interpreter's training is finalized after they have mastered the Information and Communication Technologies (ICT) including computer software, offline 
and online computer dictionaries, terminological databases, computer-aided translation tools (CAT), translation memory (TM) tools, searching engines, etc. [8].

Table 1. CLIL teaching models for mining students and those majoring in translation studies.

\begin{tabular}{|c|c|c|}
\hline & Mining students & Humanities students \\
\hline $\begin{array}{l}\text { Background } \\
\text { knowledge }\end{array}$ & $\begin{array}{l}\text { field area knowledge }(+) \\
\text { language knowledge }(-, \\
\text { or very little) }\end{array}$ & $\begin{array}{l}\text { field area knowledge }(-) \\
\text { language knowledge }(+)\end{array}$ \\
\hline $\begin{array}{l}\text { Principle aims } \\
\text { of study }\end{array}$ & $\begin{array}{l}\text { acquisition of foreign } \\
\text { language vocabulary } \\
\text { matching the field area } \\
\text { knowledge; forming and } \\
\text { improving general } \\
\text { language skills; practicing } \\
\text { vocabulary and language } \\
\text { skills in context. }\end{array}$ & $\begin{array}{l}\text { acquisition of field area knowledge } \\
\text { (forming the worldview); } \\
\text { acquisition of foreign and native } \\
\text { language vocabulary matching the } \\
\text { field area knowledge; adjustment / } \\
\text { improving general language skills; } \\
\text { practicing vocabulary and language } \\
\text { skills in context. }\end{array}$ \\
\hline Resultant aim & $\begin{array}{l}\text { the student's ability to } \\
\text { communicate on the } \\
\text { professional topics }\end{array}$ & $\begin{array}{l}\text { the student's ability to assist and } \\
\text { facilitate communication on the } \\
\text { professional topics }\end{array}$ \\
\hline \multirow[t]{2}{*}{ Methods } & \multicolumn{2}{|c|}{$\begin{array}{l}\text { Methods embrace developing all types of activities: } \\
\text { Reading is the main source of information. Input results depend } \\
\text { on using meaningful material. } \\
\text { Listening is a supportive supplementary input activity, } \\
\text { actualizing the receptive skills and providing motivation for the } \\
\text { students. } \\
\text { Writing enables practicing ('recycling') actual grammar and } \\
\text { vocabulary. } \\
\text { Speaking ensures implementing the subject knowledge and } \\
\text { language skills in contexts. }\end{array}$} \\
\hline & $\begin{array}{l}\text { developing } \\
\text { communicative skills in } \\
\text { professional contexts }\end{array}$ & $\begin{array}{l}\text { developing translating and } \\
\text { interpreting skills to accompany } \\
\text { professional communication }\end{array}$ \\
\hline $\begin{array}{l}\text { Studying and } \\
\text { supplementar } \\
\text { y materials }\end{array}$ & \multicolumn{2}{|c|}{$\begin{array}{l}\text { news and mass media texts; encyclopedic texts, subject textbooks } \\
\text { (introductory or basic level); instructive and scientific texts; case } \\
\text { study materials; materials for role-play }\end{array}$} \\
\hline $\begin{array}{l}\text { Instructor's } \\
\text { role }\end{array}$ & $\begin{array}{l}\text { to enable projecting and } \\
\text { transposing the possessed } \\
\text { knowledge on the foreign } \\
\text { language }\end{array}$ & $\begin{array}{l}\text { to enable enhancing the command } \\
\text { of the native and foreign languages } \\
\text { through exploring and cognizing a } \\
\text { new subject area }\end{array}$ \\
\hline
\end{tabular}

\section{Results and Discussion}

Speaking (or conversational) practice classes, aimed at contextual use of specific vocabulary, need to meet three requirement if given to students who have either little language skills or no background knowledge in the specific area: (1) new topic vocabulary has to be merged with an adjacent topic of a more general and familiar character; (2) this other topic must be exciting enough to serve as an impetus for discussion; (3) this topic should be "hot and happening" to cause a 'ripple on water' effect in the media, thus supplying a number of authentic texts in both languages. Such an approach can engage both humanities students (majoring in translation studies or philology), who possess foreign language skills but lack background knowledge, and bachelors of mining engineering, whose language skills often appear wanting.

It seems logical that at early stages mining issues can be merged with the environmental protection topic: the latter is both familiar and engaging and provides a number of burning 
issues to use as a conceptual core for a speaking task. As for the third requirement, the issue of indigenous peoples vs. mining development in the region is up-to-the-minute and, consequently, abundant in a substantial amount of media sources, both visual and textual. Accordingly, the momentous character of the information makes it possible to use the case study both at early and final stages of vocabulary training depending on the type and complexity of the text(s) used.

The following example demonstrates in details how this topic can be transformed into a case. Case method engages students into real-life situations, thus bridging the gap between theory and practice, and can make English classes multidisciplinary [9]. The case in question is based on the conflict between one of the Kuzbass indigenous peoples, the Shores (or Shorts), from the village of Kazas and coal mining enterprises that destroy their natural environment [10]. The conceptual core for the case is a bilingual article published by the Russian Association of Indigenous Peoples of the North [11]. The case includes the following stages.

Stage 1, introduction: students activate their environmental protection vocabulary by discussing the environmental problems in the region.

Stage 2, problem statement: they read the bilingual article mentioned above as well as some articles on mining published in official newspapers and use the material to practice its consecutive and simultaneous interpreting.

Stage 3, studying both sides evidence: in pairs or small groups, students make reports on the history and traditions of the Shorts (other possible topics: Exploring Siberia, Ethnic Minorities of Kuzbass, History of the Kemerovo Region, The Turkic peoples of Siberia, etc.) and mining development of the region (History of the Kuzbass Industry before the Revolution, The Autonomous Industrial Colony of Kuzbass, The Current State and Perspectives of Local Mining Industry, Underground and Open Pit Mining in Kuzbass, Reclamation of Industrial Areas and Conservation of Exhausted Mines, etc.).

Stage 4, fieldwork activities (these activities may include independent work, e.g. in museums, archives, databases, other related or involved organizations, enterprises, establishments): students study on-line material on the Museum of Archeology and Ethnography (the indigenous peoples' exhibition) and The Red Hill (Krasnaya Gorka) Museum (the mining exhibition), visit the museums and interpret for the guides. The first museum provides a well-organized exposition on the history and culture of local indigenous tribes, thus providing the students with background knowledge that would explain the standpoint of the indigenous peoples in the conflict. The other one offers a unique underground exposition imitating a real coal mine and a considerable number of Kuzbass's rich and exciting coal mining history, which has always reflected the history of the country itself. Facts of local history come to life at the Red Hill museum, which allows students to understand the position of the other side of the conflict.

Stage 5, search and exploration of Internet and youtube material: students choose and translate printed, audio, or video material they find on the public platforms and/or youtube site (news briefs, short documentaries, public addresses, photo-essays, etc.). They can perform consecutive and/or simultaneous interpreting in the class or create subtitles with the help of some basic free software.

Stage 6, role-play: students stage a meeting between the representatives of the Shorts ("Village Head", "Shaman", "Hunter", "UN Representative", "Anthropologist", etc.), the mining enterprise ("CEO", "Lawyer", "Mining Engineer", "Foreign Investor" etc.), the local authorities and foreign and Russian journalists while some students serve as interpreters. To discuss arising interpretation difficulties and assess the quality of the interpretation, the role-play can be filmed and analyzed. To increase the efficiency of the activities, experts may be invited to take part in the role-play or the later analysis and discussion [12]. Procedures and activities subsequent to the role-play are beyond doubts of 
paramount importance, because they build up translation management mechanisms and quality control system through assessment and formative revision. Introducing clearly defined criteria, the instructor or the expert are able to hand over operational experience concerning such aspects as translational objectives, substantive and logical characteristics of the translated texts, the context role, the pragmatic and linguistic norm.

Stage 7, practical terminology. Students perform terminological text processing of authentic texts retrieved from the regional organizations (coal mining enterprises, export companies, museums) which rely on students' terminological assistance. First, students have to learn theoretical (structural, ontological, semasiological, derivational, typological, discursive, comparative, codificational, etc.) aspects of terminology and the specific approaches to the subject matter by the national terminological schools [13]. Second, they learn CAT (computer-aided translation) tools that enable them to employ translationmemory software and reference corpora for extracting, processing, cataloguing the terms and terminological units, storing and sharing compiled glossaries [14; 15]; they learn how to establish and run a terminological bank on mining. The students' terminological work may result in mining thesauri, e-Dictionaries, terminological card-indexes of new terms, an e-Dictionary on the Kuzbass local history, economy, physical geography, economical geography of Western Siberia.

\section{Conclusion}

Translation master-degree training in an industrial region achieves the best results when former bachelors of mining and humanities study together. Such an approach allows for an exchange in experience between those proficient in language and those with prior knowledge in mining.

The sophisticated character of mining vocabulary and the complexity of the industry itself make it hard to achieve the final goal of second language learning, i.e. intercultural communication. Content and Language Integrated Learning (CLIL) method can be applied to teaching professional vocabulary, the approach that can be used with different target audiences, mining students or would-be interpreters / translators.

The method presupposes that the instructor should employ various authentic life-related media material to introduce mining vocabulary in context and make use of the one-industry city environment to let students with philological background acquire the necessary knowledge and to engage former mining students into active language practice. CLIL method makes it easier to introduce thematic cases into the learning process: they contain all possible kinds of contexts, materials, and various skill development techniques, from written translation to large-scale complicated role games.

CLIL method can be applied for further level of terminological acquisition in the sphere of mining, i.e. compiling thematic glossaries and mastering computer-aided translation tools.

\section{References}

1. J. Cenoz, Language, Culture and Curriculum, 28:1, 8-24 (2015)

2. M. L. Pérez-Cañado, International Journal of Bilingual Education and Bilingualism, 15:3, 315-341 (2011)

3. J. I. Liontas, The TESOL Encyclopedia of English Language Teaching (TESOL International Association, London, 2018)

4. D. Coyle, P. Hood, D. Marsh, CLIL, 173, 345-352 (2010) 
5. Promoting Language Learning and Linguistic Diversity: An Action Plan 2004 - 2006, (Brussels, Commission of the European Communities, 2003)

6. T. Nikula, P. Moore, International Journal of Bilingual Education and Bilingualism, 15:4. 877-898 (2016)

7. Davis C. Wilcock E. Teaching materials using case studies (UK Centre for Materials Education, Higher Education Academy, London, 2018)

8. M. Tymoczko, The Translator, 15:2, 401-421 (2014)

9. L. Kolonja, R. Stanković, I. Obradović, O. Kitanović, A. Cvjetić, Knowledge Management Research \& Practice, 14:4, 445-456 (2017)

10. L.A. Konyaeva, N.V. Rabkina. The Destruction of the village of Kazas: internet-media as material for case at English classes, 11:2, 48-50 (2016)

11. D. Berezhkov, Coal Mining in Kemerovo oblast, Russia (News, Kemerovo, 2018)

12. L. Brunette, The Translator, 6:2, 169-182 (2014)

13. S. Montero-Martínez, M. García de Quesada, Perspectives, 11:4, 293-314, (2010)

14. S. Hanoulle, V. Hoste, A. Remael, Perspectives, 23:3, 359-374, (2015)

15. J. Moorkens, S. Doherty, D. Kenny, S. O'Brien, Perspectives, 22:3, 291-303, (2013) 